\title{
Primary renal MALToma: A rare differential diagnosis for a recurrent renal mass after primary ablative therapy
}

\author{
Francesca Vedovo, MD; Nicola Pavan, MD;* Giovanni Liguori, PhD;* Salvatore Siracusano, MD;* \\ Rossana Bussani, MD; ${ }^{\dagger}$ Carlo Trombetta, MD*
}

*Department of Urology, Cattinara Hospital, Trieste, Italy; ${ }^{\dagger}$ Department of Pathology, Cattinara Hospital, Trieste, Italy

Cite as: Can Urol Assoc J 2014;8(5-6):e442-4. http://dx.doi.org/10.5489/cuaj.1645 Published online June 19, 2014.

\section{Abstract}

We report a case of primary renal lymphoma of mucosa-associated lymphoid tissue in an 82-year-old woman. She presented with a history of renal mass previously treated with kidney percutaneous cryoablation at another centre.

\section{Introduction}

Although kidney involvement is not uncommon in systemic lymphoma, primary renal lymphoma is rarely reported. Extranodal marginal zone B-cell lymphoma of mucosa-associated lymphoid tissue (MALT), first described by Isaacson and Wright in $1983,{ }^{1}$ is now well-established in the World Health Organization (WHO) classification as a distinct subtype of lymphoma.

Despite the observation that MALT lymphoma has long been limited to the gastrointestinal tract, its occurrence is now common in a variety of organs, including the ocular adnexa, breast, respiratory tract, salivary gland, thymus, thyroid, skin, gall bladder and uterine cervix. ${ }^{2}$

Malt lymphomas usually occur in adults and are often associated with autoimmune disease or chronic inflammation.

Primary renal MALToma was first described by Colovic in $1999 .{ }^{3}$ To the best of our knowledge, only 8 cases have been published until now (Table 1). ${ }^{2-9}$ We report a case of primary renal lymphoma of mucosa-associated lymphoid tissue in an 82-year-old woman who presented with a 5-cm solid mass in the left kidney.

\section{Case report}

An 82-year-old woman was presented with a history of renal mass previously operated on at another department with percutaneous cryoablation. Her medical history also included hypertension, hiatal hernia, multinodular goiter and ischemic heart disease.

At presentation, her abdominal computed tomography (CT) showed a 2.7-cm small solid mass in the left kidney and the patient elected to undergo percutaneous cryoablation of the renal mass because of its minimal invasiveness. Needle biopsy was executed, but no clear outcome could be defined from the analysis.

After a 6-month follow-up, the patient came under our observation with an abdominal CT revealing that the renal mass had doubled in size $(50 \times 40$ vs. $27 \times 20 \mathrm{~mm})$; lymphadenenopathy of the renal artery was also detected. All of the laboratory data were normal range and her physical examination was unremarkable.

Radical nephrectomy, with formal lymph node dissection, was then performed.

Macroscopically, the mass was $70 \times 32 \times 34 \mathrm{~mm}$, not involving the collecting system or the renal vein. An histology of the mass revealed subtotal, diffuse replacement of the normal kidney architecture by malignant neoplasm composed predominantly of small lymphoid cells and eosinophilis.

The neoplastic cells surrounded glomeruli and invaded renal tubules forming lymphoepithelial lesions. At high power, neoplastic cells had round or slightly irregular nuclear contours with inconspicuous nucleoli and abundant eosinophilic cytoplasm. The uninvolved kidney was normal.

Immunohistochemical analysis showed positivity for CD138, CD20, CD3 and CD43, while CD10, CD30 and bcl-6 were negative. CD3 was highly expressed by T cells that surrounded the neoplasm. Ki 67 showed a proliferative index of $5 \%$. The histological analysis led to the diagnosis of lymphoplasmacytic MALT lymphoma.

Since MALT lymphomas are predominantly localized in the gastrointestinal tract, the patient underwent a gastroscopy to assess the presence of other lymphoma localization.

After a hematological evaluation, the patient started therapy with 4 cycles of rituximab. Our patient was disease-free at the subsequent 10-month follow-up. 


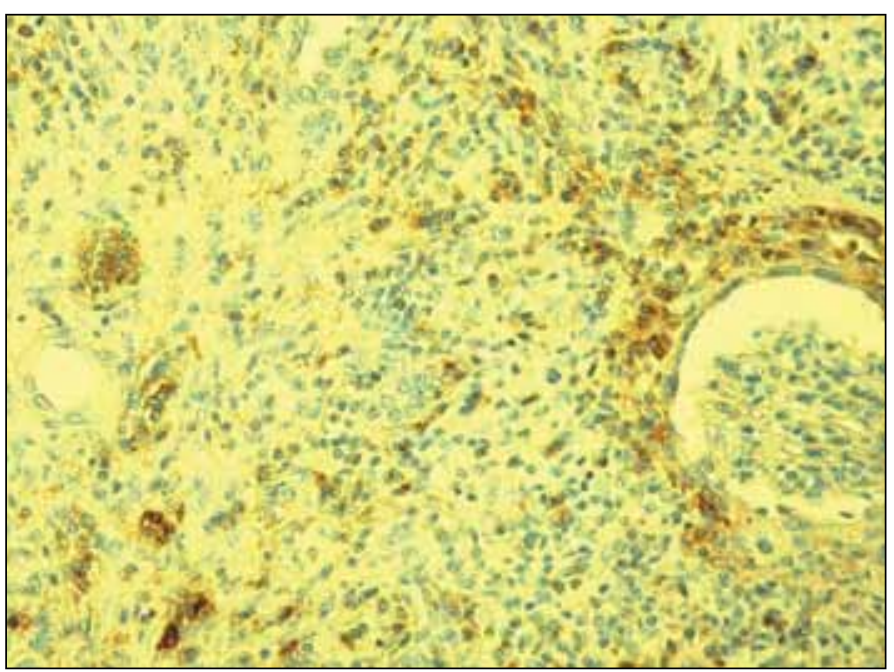

Fig. 1. Nephrectomy specimen. Sheets of lymphoma cells infiltraiting between glomeruli and renal tubuli (hematoxylin-eosin, original magnification $\times 20$ ).

\section{Discussion}

Primary renal lymphoma is very rare. It is defined as a nonHodgkin's lymphoma arising in the renal parenchyma in the absence of any extrarenal localization at the time of diagnosis or invasion from an adjacent lymphomatous mass..$^{1,3,4}$

The MALT lymphomas are in the group of marginal zone B-cell lymphomas that arise from extranodal mucosal-based proliferation of lymphoid cells. These cells have been called centrocyte-like cells or monocytoid B cells, often infiltrating normal epithelial structures with formation of so-called lymphoepithelial lesions.

Although MALToma are usually preceded by chronic inflammation (e.g., gastric MALT lymphoma is usually associated with $\mathrm{H}$. pylori gastritis) for renal MALT lymphomas, no specific predisposing condition has been identified. The preoperative diagnosis of MALT-type lymphoma of the kidney has always been difficult.

In accordance with the 8 cases analyzed in the literature, ${ }^{1,2,7-10}$ our patient did not show specific symptomatology. In the previously recorded cases, clinical manifestations included hypertension, anorexia, weight loss and frequent urination; the non-specificity of these symptoms does not lead to a secure diagnosis of MALT lymphoma.

In the same way, medical imaging and laboratory examinations do not present specific findings. Uni- or bilateral kidney enlargement had been proposed in the past as one of the criteria to diagnose primary renal lymphoma; however, our case questions this criterion by presenting a solitary renal mass. ${ }^{9}$

In the imaging, renal MALToma often mimics other kidney diseases, such as renal cell carcinoma, angiomyolipoma, oncocytoma, renal pelvic carcinoma, other types of

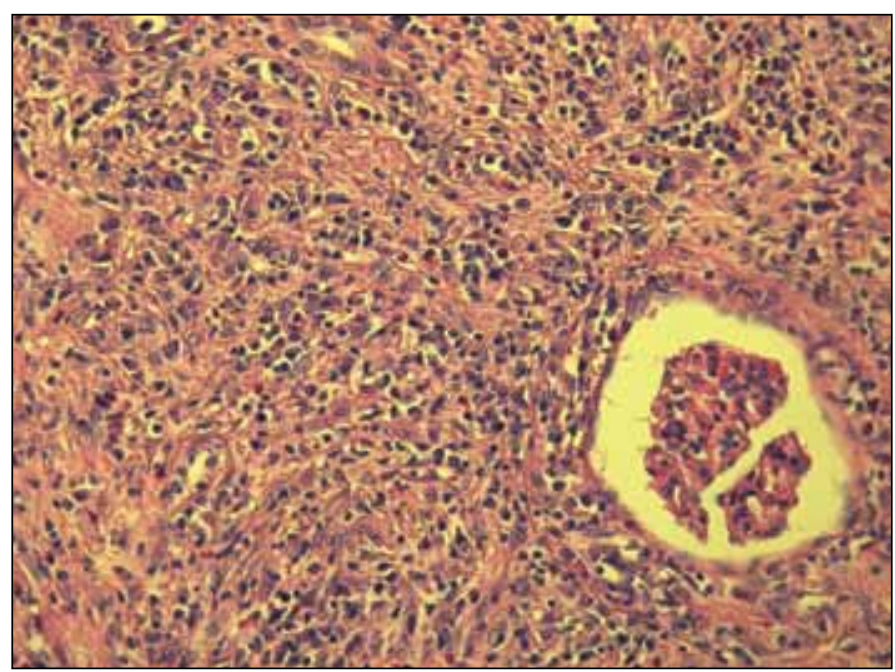

Fig. 2. Multifocal CD138 positive stain of lymphoid cells consistent with MALT lymphomaa (CD138, original magnification $\times 20$ ).

lymphoma and xanthogranulomatous pyelonephritis - all of which should be considered in the differential diagnosis. Immunophenotype is less specific. ${ }^{9}$

In our case, the neoplasm was diagnosed as a MALTtype lymphoma because of the presence of lymphoepithelial lesions, centrocyte-like cells admixed with reactive lymphocytes, plasmacytoid cells and plasma cells with the characteristic immunophenotype (e.g., CD138, CD20, CD3, CD43 positivity and CD10, CD30, bcl-6 negativity).

Despite the successful and safe use of renal biopsy of native kidneys using real-time ultrasound, in our case there was no suspicion of a lymphoproliferative disease and tumour biopsy was not performed. According to the European Association of Urology guidelines, renal tumour biopsy is not necessary before surgery in fit patients with

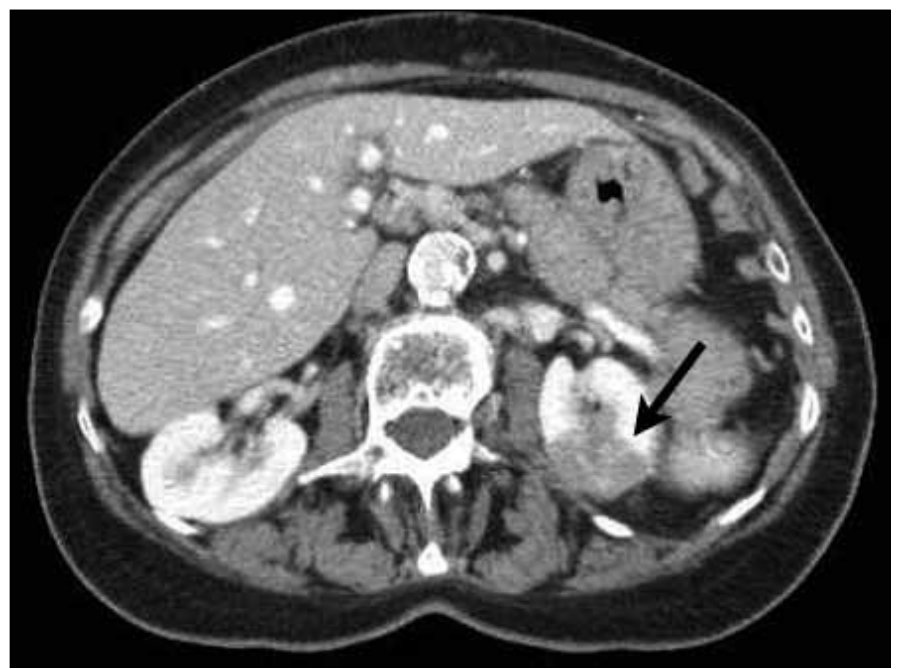

Fig. 3. Computed tomography aspect of renal mass. 


\begin{tabular}{|c|c|c|c|c|c|c|c|}
\hline Cases & Authors & $\begin{array}{c}\text { Publication } \\
\text { year }\end{array}$ & Age/sex & Signs and symptoms & Size $(\mathbf{c m})$ & Treatment & Follow-up \\
\hline 1 & $\begin{array}{l}\text { Colovic et } \\
\text { al. }^{2}\end{array}$ & 1999 & $50 / \mathrm{M}$ & Hypertension & $6 \times 5 \times 3$ & Nephrectomy & Not available \\
\hline 2 & $\begin{array}{l}\text { Mhawech } \\
\text { et al. }{ }^{3}\end{array}$ & 2000 & $76 / F$ & $\begin{array}{l}\text { Right flank pain, } \\
\text { anorexia, weight loss, } \\
\text { hypertension }\end{array}$ & $5 \times 3 \times 3.2$ & Radical nephrectomy & Not available \\
\hline 3 & Jindal et al. ${ }^{4}$ & 2001 & $45 / M$ & $\begin{array}{l}\text { Fever, abdominal } \\
\text { pain with multiple } \\
\text { relapses }\end{array}$ & $4 \times 3 \times 3$ & $\begin{array}{l}\text { Radical nephrectomy, } \\
\text { chemotherapy }\end{array}$ & Alive for 13 years \\
\hline 4 & Tuzel et al. ${ }^{5}$ & 2003 & $43 / \mathrm{M}$ & --- & -- & Radical nephrectomy & $\begin{array}{c}\text { Disease-free at } 28 \\
\text { months }\end{array}$ \\
\hline 5 & Qiu et al. ${ }^{6}$ & 2006 & $53 / \mathrm{M}$ & Abdominal screening & $2.5 \times 1.9$ & Partial nephrectomy & $\begin{array}{l}\text { No evidence of } \\
\text { recurrence at } 10 \text { months }\end{array}$ \\
\hline 6 & $\begin{array}{l}\text { Yoichiro et } \\
\text { al. }^{7}\end{array}$ & 2008 & $30 / \mathrm{M}$ & $\begin{array}{l}\text { Frequent urination, } \\
\text { lower abdominal pain }\end{array}$ & $4 \times 2.5 \times 2.7$ & Radical nephrectomy & $\begin{array}{c}\text { Disease-free at } 21 \\
\text { months }\end{array}$ \\
\hline 7 & $\begin{array}{l}\text { Contreras } \\
\text { et al. }{ }^{8}\end{array}$ & 2010 & $71 / \mathrm{M}$ & Macro hematuria & $3.4 \times 4.2$ & Radical nephrectomy & Not available \\
\hline 8 & $\begin{array}{c}\text { Charitaki et } \\
\text { al. }{ }^{9}\end{array}$ & 2011 & $66 / F$ & $\begin{array}{l}\text { Acute kidney injury, } \\
\text { hypertension }\end{array}$ & Normal size & $\begin{array}{l}\text { Chemotherapy (R-CHOP), } \\
\text { kidney cryoablation }\end{array}$ & Disease-free at 3 years \\
\hline 9 & Present case & 2014 & $82 / F$ & Hypertension & $7 \times 3.2 \times 3.4$ & $\begin{array}{c}\text { Cryoablation, radical } \\
\text { nephrectomy, rituximab }\end{array}$ & Disease-free at 8 months \\
\hline
\end{tabular}

a long life expectancy and a clearly suspicious, contrastenhancing renal mass at abdominal CT.

The biological behaviour of the disease generally differs from the nodal low-grade B-cell lymphoma. Because lowgrade MALT-type lymphomas often have an indolent clinical course with a tendency to be localized at the time of diagnosis and could be curable with local therapy, it is important to distinguish MALToma from other renal lymphomas that have a more aggressive clinical course. The therapeutic strategies and the staging to MALT-type lymphoma involved in extranodal sites have not been well-defined, especially regarding the kidney. Resection, combination chemotherapy, and consolidation radiotherapy are the suggested treatment options for primary renal lymphomas. ${ }^{10}$

In our case, the patient was previously operated on at another centre with kidney percutaneous cryoablation. She was then surgically treated and received the monoclonal antibody (rituximab). She was disease-free at her recent 10 month follow-up visit.

\section{Conclusion}

Our case further confirms that primary renal MALT-type lymphoma can occur in the kidney and should be included in the differential diagnosis of a solitary renal mass. However, because the disease may have a very indolent course and may recur, longer follow-up is necessary before suggesting that surgery alone can cure localized renal MALT-type lymphoma.
Competing interests: Dr. Vedovo, Dr. Pavan, Dr. Liguori, Dr. Siracusano, Dr. Bussani and Dr. Trombetta all declare no competing financial or personal interests.

This paper has been peer-reviewed.

\section{References}

1. Isaacson P, Wright DH. Malignant lymphoma of mucosa-associated lymphoid tissue. A distinctive type of B-cell lymphoma. Cancer 1983;52:1410-6. http://dx.doi.org/10.1002/10970142(19831015)52:8<1410::AID-CNCR2820520813>3.0.C0;2-3

2. Kato $Y$, Hasegawa $M$, Numasato $S$, et al. Primary mucosa-associated lymphoid tissue-type lymphoma arising in the kidney. Int J Urol 2008;15:90-2. http://dx.doi.org/10.1111/j.1442-2042.2007.01923.x

3. Colovic M, Hadzi-Diokic J, Cemerikic V, et al. Primary MALT lymphoma of the kidney. Hematol Cell Ther 1999;41:229-32. http://dx.doi.org/10.1007/s00282-999-0229-x

4. Mhawech P, Ahearn J, Mederios J. Pathologic quiz case: A unilateral renal mass in an elderly woman. Arch Pathol Lab Med 2000;124:919-20.

5. Jidal $B$, Sharma SC, Das A, et al. Indolent behavior of low-grade B cell lymphoma of mucosa-associated lymphoid tissue arising in the kidney. Urol Int 2001;67:91-3. http://dx.doi.org/10.1159/000050955

6. Tuzel E, Mungan MU, Yorukoglu K, et al. Primary renal lymphoma of mucosa-associated lymphoid tissue. Urology 2003;61:463 [abstract]. http://dx.doi.org/10.1016/S0090-4295(02)02267-7

7. Qiu L, Unger PD, Dillon RW, et al. Low-grade mucosa-associated lymphoid tissue lymphoma involving the kidney: Report of 3 cases and review of the literature. Arch Pathol Lab Med 2006;130:86-9.

8. Contreras-lbà-ez J.A, Diaz-Gomez L, Muriel-Cueto P. Carcinoma renal de células claras sincrònico con linfoma no hodgkiniano de fenotipo B de tipo MALT. Actas Urol Esp 2010;34:815-26.

9. Charitaki E, Liapis K, Moutzouris DA, et al. Primary renal MALT lymphoma presenting with cryoglobulinaemia. Nephrol Dial Transplant 2011;26:3819-21. http://dx.doi.org/10.1093/ndt/gfr478

10. Okuno SH, Hoyer JD, Ristow K, et al. Primary renal non-Hodgkin's lymphoma: An unusual extranodal site. Cancer 1995;75:2258-61. http://dx.doi.org/10.1002/1097-0142(19950501)75:9<2258::AlDCNCR2820750911>3.0.C0;2-S

Correspondence: Dr. Nicola Pavan, Department of Urology, Cattinara Hospital Strada per Fiume 447, 34149 Trieste; nicpavan@gmail.com 